\title{
Cultural and Geological Heritage in Time Elapsed During Historical Kingdoms in Yogyakarta Special Region, Indonesia
}

\section{Sri Mulyaningsih}

Geological Engineering, Faculty of Mineral Technology, Institut Sains \& Teknologi AKPRIND Yogyakarta, Indonesia

\begin{abstract}
Yogyakarta, Indonesia is known for its kingdom government system for all its living history; since 8-10th century Mataram Hindu-Buddhist temples to the present Muslim Ngayogyokarto Hadiningrat. Those stretch of history resulted in many artefacts and chronicles. A cultural imaginary line that linking Merapi Volcano in the north and the Indian Ocean in the south through the Yogyakarta Palace in the middle has a sacral geo-cultural heritage, explaining a prosperity gentle volcanic town, a beautiful scheme of the open panoramic features with several temples standing on the plain and mountainous landscapes in between the rest of earthquakes and the volcanic eruptions. Many temples were partly buried under volcanic materials, and some others show evidence of being shaken several times by earthquakes. Boulders of volcanic materials varying in size and shapes are present in the plain of Yogyakarta, near Cangkiringan, Ngemplak and Ngaglik. Landslides exposed many geological features, such as faults, rock formation and stratigraphy, and some unstable slopes. Cultural and geological heritages at Yogyakarta Region were created over the time.
\end{abstract}

Keywords: geo-cultural heritage, historical kingdoms, Yogyakarta

Copyright (C2021. FOSI. All rights reserved.

A Special Publication of abstracts and extended abstracts from the conference in honor of the retirement of Prof. Yahdi Zaim, IPU (22-23 March 2021). 


\section{INTRODUCTION}

The cultural history of Yogyakarta, Indonesia (Figure 1), dated back to the Old Mataram Kingdom in $8-10^{\text {th }}$ century, Muslim Mataram Kingdom in 15-18 th century, and Ngayogyakarta Hadiningrat since $19^{\text {th }}$ century when the first Sultan held the title of the king, until the present Hamengkubuwono the 10 th (Mulyaningsih, 2016). Undocumented artifacts as the remains of the civilizations i.e., buildings, foundations, and ceramics, filled up the area since the $1^{\text {st }}$ century (Mulyaningsih, 2006). Hindu-Buddhist temples from 8-10th century are commonly found at the area (Mulyaningsih, 1999) while palaces, graves, historical buildings and mosques of the 15-19th century and the chronicles of Babad Tanah Jawa, Babad Mataram and Babad Mangir are cultural heritages that have been well conserved by Indonesian law.

The plain of Yogyakarta is geomorphologically bordered by Southern Mountain in the southeast, Kulonprogo Mountain range in the west, Merapi volcano in the north and the Javanese southern sea (Indian Ocean) in the south. The socio-cultural people of Yogyakarta invented a unique imaginary line connecting the volcano and the ocean, with Yogyakarta Palace

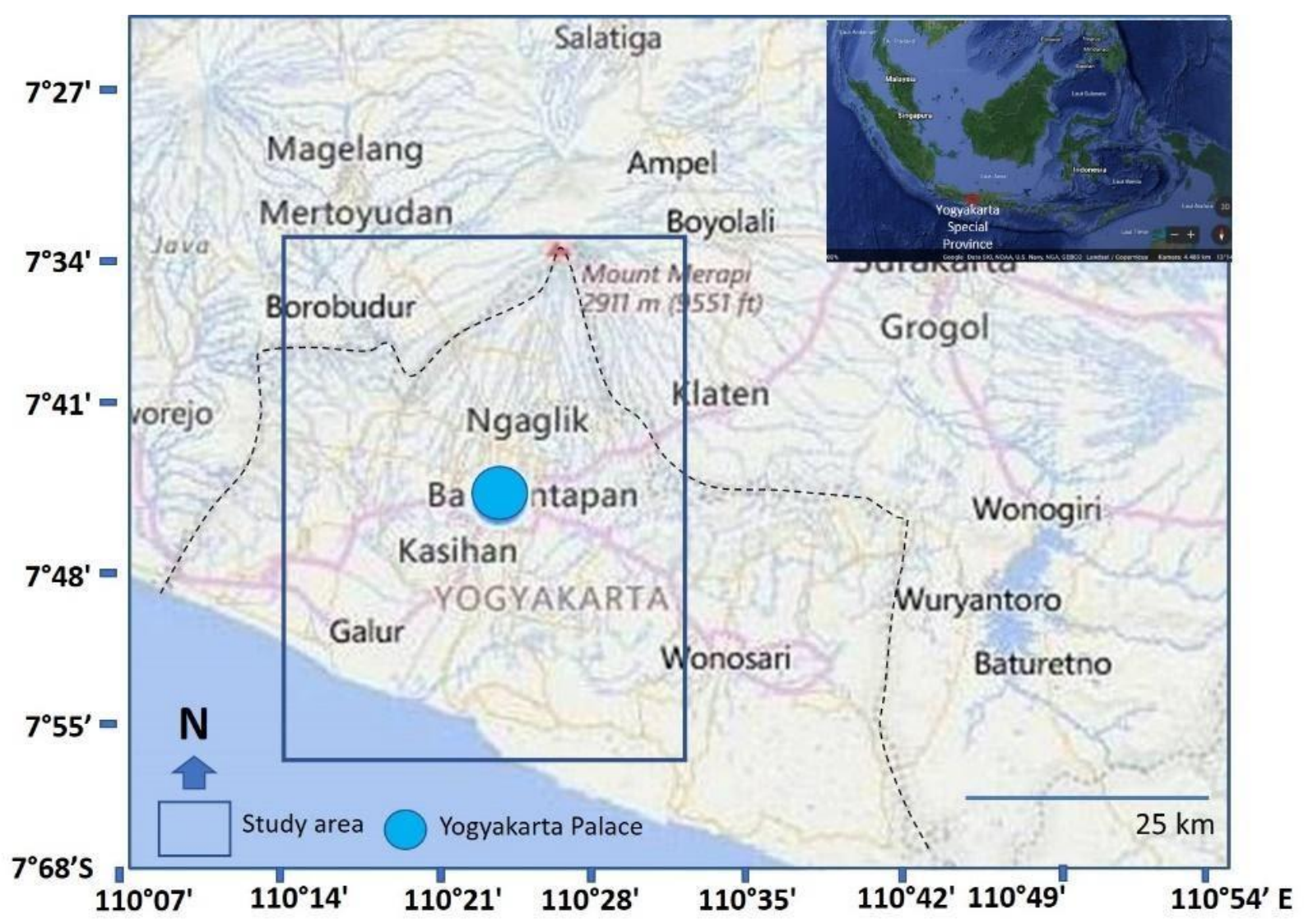

Figure 1. Situation map of study area. 
in the middle. The line represents sacral moments of the union between the Lord and the people in the Javanese geo-cultural philosophy. Paleo-geological environmental and sub classical systems explained the relationship sequentially and completely. The area is a fertile volcanic plain, beautifully open to a panoramic scene that features numerous old temples spreading on the plain until it meets the mountainous range in the east and the sea to the south.

The Merapi Volcano is one of the world's most active volcanoes, with at least one activity in 2-5 years' time duration recorded. An eruption on October 15, 2010, disorganized some villages around the volcano (Rakhman, 2021) and a glowing avalanche on November 22, 1994, buried a beautiful and sacral village at Turgo area, taking as many as ninety life casualties (Setyawati et al., 2015). There are also records of earthquakes in and around Yogyakarta since 1867 AD. Daryono et al. (2018) reported 12 fatally earthquakes since 1840 , i.e., 1840 , 1859 that followed by tsunami, 1867 , 1875, 1937, 1943, 1957, 1981, 1992, 2001, 2004, and 27 May 2006. These previous studies confirmed that Yogyakarta has unique geological condition and cultural heritages associated with it. The frequent but unpredicted threat of volcanic and tectonic activities of the area effect the people's way of life as cultural heritage. This paper discusses the relationship between the two aspects.

\section{METHODOLOGY}

The paper is a compilation of previous studies that were rewritten and resynthesized. The cultural heritage facts and studies were collected from historians while the geological aspects were based on the results of geological heritage verification in Yogyakarta by the Geological Agency. The verification studies were then proposed after a letter from the Ministry of Energy and Mineral Resources in 2019 and 2020, to determine as many as 20 geo-sites as geo-heritage locations. All data were compiled based on librarian method, analyzed, and synthesized by inducting method.

\section{RESULTS}

There are 20 geo-sites in and around Yogyakarta to compliment Merapi Volcano Geopark and Gunungsewu Geopark. The study on Merapi Geopark itself is still ongoing, but it will be an important treasure of Yogyakarta. This study will combine the geological aspects of the important historical sites regarding their position surrounding the named geoparks.

Yogyakarta has a long-recorded history since $6^{\text {th }}$ century of Kalingga Kingdom, then Old Mataram Kingdom in 8-10th century and Muslim Mataram Kingdom since $16^{\text {th }}$ century (Muthiah et al., 2018). Many parallel relics were found in Yogyakarta, i.e., Hindu and Buddhist temples, several unknown structures, chronicles, and so on. (Mulyaningsih, 2006; Mulyaningsih et al., 2006; Figure 2). 
The first geo-historical site is Morangan Temple, located in the upper flank of Merapi Volcano as far as $14 \mathrm{~km}$ from the crater. The base of temple has not been exposed since pyroclastic density currents, grain supported lahars and muds in four sequences separated by unconformably field

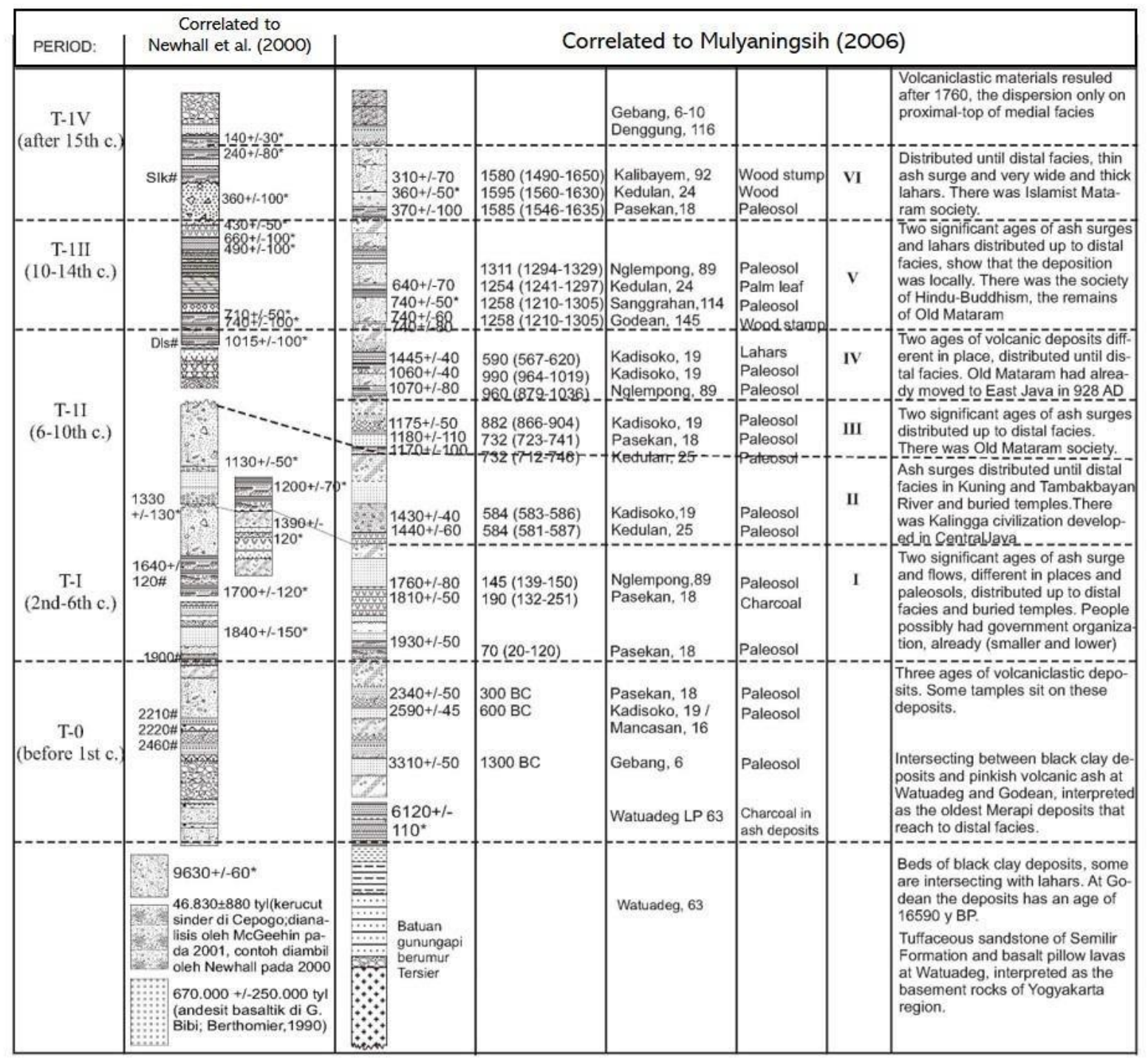

Legend :

\begin{tabular}{|c|c|c|}
\hline Pyroclastic deposits & Lahars & Fluvial deposits \\
\hline Pyroclastic fall dep. & Distal lahars & Conglomerate \\
\hline Pyroclastic surge dep. & P. Proximal lahars & 祭園 Clays \\
\hline Unidentified ash dep. & $\begin{array}{l}\text { Lahars rich charcoal, } \\
\text { leafs and woods }\end{array}$ & ripple structure \\
\hline Pyroclastic flow dep. & Evaleosol & $\begin{array}{l}\text { Beds of loose sand } \\
\text { Ash-fine sand }\end{array}$ \\
\hline
\end{tabular}

\begin{abstract}
* ages by Newhall et al. (2000) \# ages by Andreastuti et al. (2000)

Number behind name of type location represents to field number.

The periods are classified based on 14-C ages of the soil foundation below the temples. 14-C ages of paleosol represent to the ages of the burying of those paleosols.
\end{abstract}

Table 1. Stratigraphic correlation of study area according to Newhall et al. (2000) of the Merapi proximal area (near summit) and Mulyaningsih (2006) on the medial-distal area (around the temple's area). 


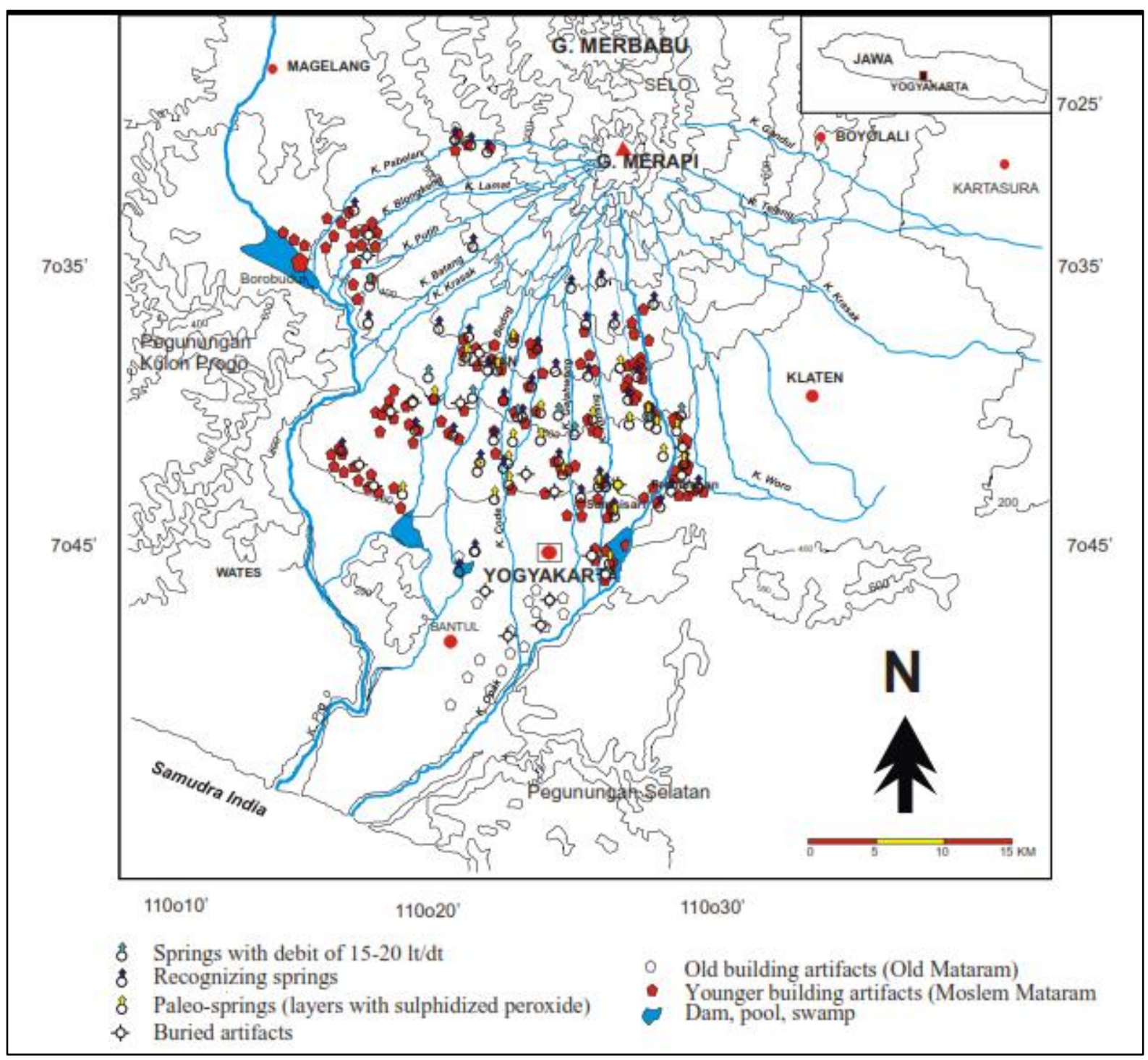

Figure 2. Buried temples, wells, dams, and others; artifacts relic of Old Mataram kingdom and Muslim Mataram kingdom exposed at study area (Mulyaningsih, 2006).

erosions buried the buildings. Those materials were the volcanic debris from part of Merapi crater that collapsed to the east-south-southwest during a big eruption. Most of the stones are cracked with undulated piling, presumably by earthquakes. Pyroclastic density currents of 2010's Merapi eruption evidently also reached this area. The second site is Kedulan Temple, located on medial facies of the volcano, $22 \mathrm{~km}$ from the crater to the south. The whole buildings were buried by pyroclastic surges, lahars, and muds. The base of the buildings, Perwara, the Yoni's and the Nandi's holders were bumped. The pyroclastic density currents were known from $1445 \pm 40$ yBP $\left(5^{-6} 6^{\text {th }}\right.$ century). The volcanic materials and earthquakes surged the temples' buildings, disorganized them, then buried them. The third temple is Kadisoko Temple, $20 \mathrm{~km}$ from Merapi that is totally 
buried by 4 sequences of volcanic eruptions (Table 1). There was stem of 680 \pm 100 yBP (1285-1390 AD) within the deposits of pyroclastic that aged from $1170 \pm 100 \mathrm{yBP}(780-870 \mathrm{AD})$.

Next to mention is Plaosan Temple which located $2 \mathrm{~km}$ to the east and similar in size with the well conserved
Mulyaningsih et al. (2006) reported that based on volcano-stratigraphy analysis, there were known periods of Merapi volcano activities that took place in 1-3 centuries, 5-10 centuries, 12-15 centuries, and 16-17 centuries. Particularly to the activities that took place in $12-15^{\text {th }}$ centuries, the intensity was increased, exhibited by

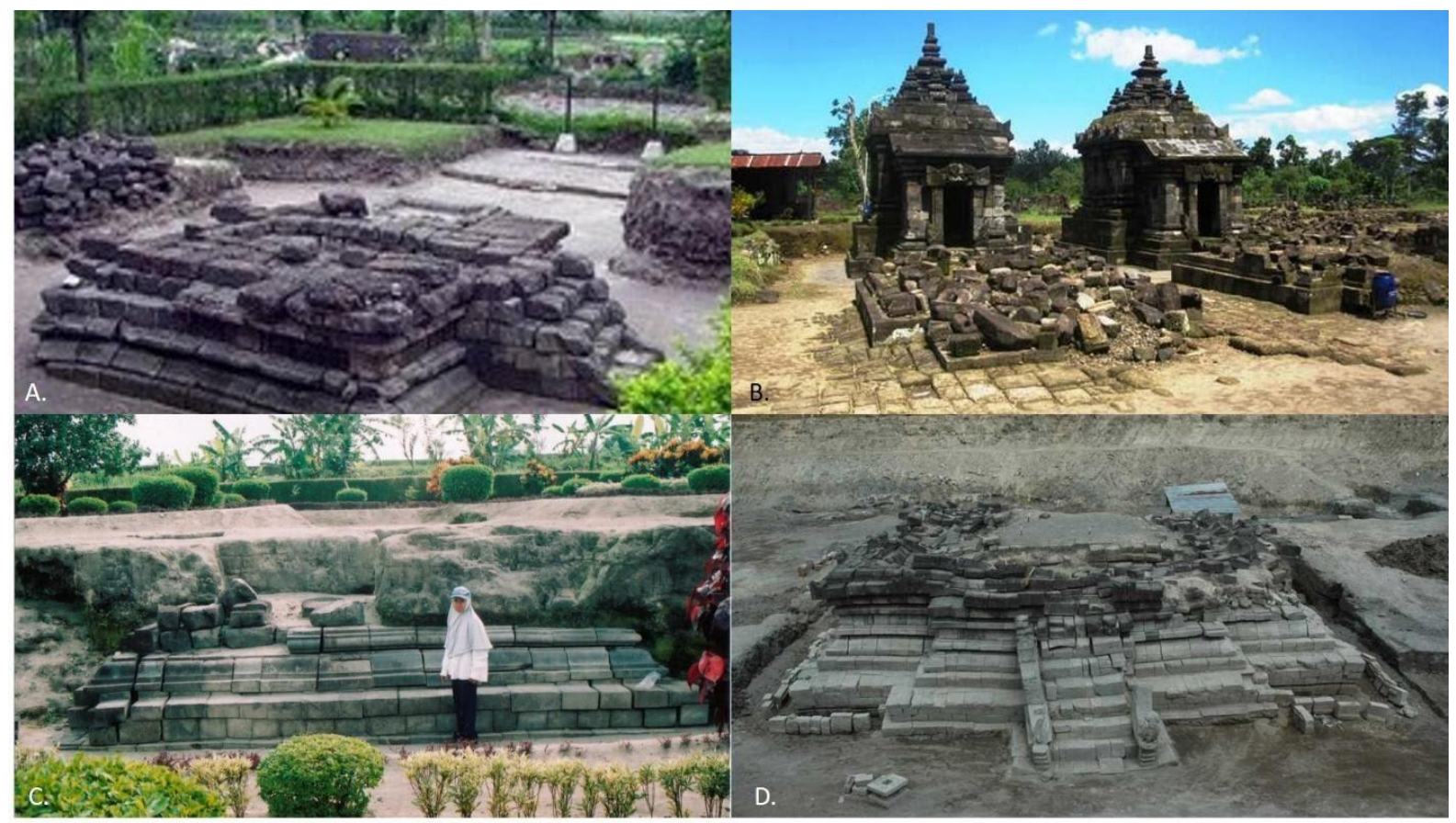

Figure 3. A. The buried Gampingan Temple $32 \mathrm{~km}$ from the Merapi's summit, $B$. The bumpy base of Plaosan Temple (24 km from the summit); $C$. Kadisoko Temple that buried by 4 sequences volcanic deposits, $20 \mathrm{~km}$ from the summit; and D. Kedulan

Temple (19-20 $\mathrm{km}$ from the summit) before reconstruction.

Jonggrangan (Prambanan) Temple. The fence of Plaosan was buried by 5 7 meters thick volcanic ash materials, consisting of lahars and ash. Within the materials are ceramic fragments, statues, and broken stupas with $1070 \pm 80$ yBP paleosol age below them. There are many more old temples and buildings which are in a similar condition with the said temples. the collapsing temples caused by volcanic eruptions and earthquakes. During the period, Mulyaningsih (2006) identified 3-5 sequences of volcanic deposits consisting of dense pyroclastic currents and lahar and at least 12 times of earthquakes which triggered disasters.

Despite the disaster it caused, volcanic eruptions supported people's culture 
development. The $1445 \pm 50 \mathrm{yBP}$ of pyroclastic deposits; the $1175 \pm 50 \mathrm{yBP}$, $1070 \pm 45 \mathrm{yBP}$, and $740 \pm 50 \mathrm{yBP}$ of pyroclastic deposits and lahars; and $370 \pm 50 \mathrm{yBP}$ of pyroclastic deposits, ashes, muds, and lahars; and the bumpy old buildings are geo-cultural heritages that should be conserved for their importance in education of disaster management, geology, volcanology, history and culture (Permadi et al., 2014).

Mulyaningsih $(2005,2006)$ mentioned that temples were built before $200 \mathrm{AD}$, before $600 \mathrm{AD}$, many before $882 \mathrm{AD}$ to before 1252-1285 AD. Based on the study, the temples were collapsing in different time and mechanism (Figure 3). Most of the temples' floor were cracked and bumpy, in evidence of repeatedly earthquake shaking to the buildings.

At times, the temples might have not collapsed completely but abandoned when people changed their religion and way of life. After the coming of Islam in $15^{\text {th }}$ century, the temples were no longer place of worship nor maintained. As they were abandoned and hit by volcanic eruptions and earthquakes, there were no community efforts to repair and rebuild them. Eventually, the old temples were damaged, collapsed and buried. Referring to study research on Borobudur Paleo-Lake to the west of Merapi near Borobudur Temple, the shallowing of Lake Borobudur was caused by tectonic activity which resulted in rifting and faulting and triggered landslides that buried the abandoned majestic temple. (Murwanto et al., 2013).

\section{CONCLUSION}

Merapi is an active volcano with pyroclastic density currents, hot avalanche of ashes, muds, and lahars that frequently threat the plain of Yogyakarta and its people. On the other hand, volcanic deposits bring fertility to agricultural people and the volcano added grandeur to the city. As a living tradition, Yogyakarta Palace and its surrounding settlements lay at the golden corridor between Merapi Volcano as the source of prosperity, the ocean as its wealth and power, and the mountain range as its influence. Tectonism in the forms of earthquakes and tsunami from the southern sea has added a long line of geological disasters to Yogyakarta area that shaped and matured the socio-cultural life of its people. The local wisdom by completely lay their fate and destiny to the Almighty grows in the essence of the imaginary line of Merapi, the city of Yogyakarta and the southern Sea. It is the basic concept to develop and conserve geo-cultural heritages around Merapi Geoparks and for further education of disaster management, geology, volcanology, history and culture of the area.

\section{ACKNOWLEDGEMENTS}

Funding for this study was partly provided through the last year of PTUPT grant. Most discussion was done under supervision by Prof. Sampurno, Prof. Yahdi Zaim, and Prof. Denny Juanda Puradimaja during PhD Thesis. Common analyses especially in geo-heritage developments were 
supported by the Local Government of Yogyakarta Special Province.

\section{REFERENCES}

Daryono, D., Brotopuspito, K. S. and Sutikno, S., 2018. Hubungan antara Indeks Kerentanan Seismik dan Rasio Kerusakan pada satuan bentuk lahan di Zona Graben Bantul Yogyakarta. In Proceeding, Seminar Nasional Kebumian Ke-11 Perspektif Imu Kebumian Dalam Kajian Bencana Geologi Di Indonesia 5-6 September 2018. Departemen Teknik Geologi.

Muthiah, J., Muntasib, E. K. S. H. and Meilani, R., 2018. Tourism hazard potentials in Mount Merapi: how to deal with the risk. In IOP Conference Series: Earth and Environmental Science (Vol. 149, No. 1, p. 012020). IOP Publishing.

Mulyaningsih, S., Sampurno, S., Zaim, Y., Puradimaja, D. J., Bronto, S. and Siregar, D. A., 2006. Perkembangan geologi pada kuarter awal sampai masa sejarah di dataran Yogyakarta. Indonesian Journal on Geoscience, 1(2), 103-113.

Mulyaningsih, S., 2006. Geologi lingkungan di daerah lereng selatan Gunung Api Merapi, pada waktu sejarah (Historical time). Disertation in Departemen Teknik Geologi, Sekolah Tinggi Pascasarjana Institut Teknologi Bandung. DOI, 10.
Murwanto, H., Siregar, D. A. and Purwoarminta, A., 2013. Jejak erupsi Gunung Merapi di Kabupaten Magelang Provinsi Jawa Tengah. Jurnal Lingkungan dan Bencana Geologi, 4(2), 135-147.

Permadi, R., Rachwibowo, P. and Hidajat, W.K., 2014. Potensi SitusSitus Warisan Geologi di Area Kars Gunung Sewu sebagai Pendukung dan Peluang Pengembangan Geopark di Indonesia untuk Aset Geowisata Kreatif. Geological Engineering $E$ Journal, 6(2), 586-601.

Rakhman, A.N., 2021. Kesiapsiagaan Rumah Tangga Menghadapi Gempa Berbasis Sejarah Dan Kearifan Lokal Di Desa Tlogoadi, Sleman. In Prosiding Seminar Nasional LPPM.

Setyawati, S., Hadi, B.S. and Ashari, A., 2015. The Analysis of Eruption Hazard of the Merapi Volcano After 2010 Eruption Disasters. In Proceedings 9th International Conference on Malaysia-Indonesia Relations (PAHMI 9). 